\title{
An ice-core record of Antarctic sea-ice extent in the southern Indian Ocean for the past $\mathbf{3 0 0}$ years
}

\author{
C. XIAO, ${ }^{1,2}$ T. DOU, ${ }^{3,1}$ S.B. SNEED, ${ }^{4}$ R. LI, ${ }^{2}$ I. ALLISON ${ }^{5}$ \\ ${ }^{1}$ State Key Laboratory of Cryospheric Sciences, Cold and Arid Regions Environmental and Engineering Research Institute, \\ Chinese Academy of Sciences, Lanzhou, Gansu, China \\ E-mail: cdxiao@lzb.ac.cn \\ ${ }^{2}$ Institute of Climate System, Chinese Academy of Meteorological Sciences, Beijing, China \\ ${ }^{3}$ College of Resources and Environment, University of Chinese Academy of Sciences, Beijing, China \\ ${ }^{4}$ Institute of Climate Change, University of Maine, Orono, ME, USA \\ ${ }^{5}$ Antarctic Climate and Ecosystems Cooperative Research Centre, Hobart, Tasmania, Australia
}

\begin{abstract}
The differing response of ice extent in the Arctic and Antarctic to global average temperature change, over approximately the last three decades, highlights the importance of reconstructing long-term sea-ice history. Here, using high-resolution ice-core records of methanesulfonate $\left(\mathrm{MS}^{-}\right)$from the East Antarctic ice sheet in Princess Elizabeth Land, we reconstruct southern Indian Ocean sea-ice extent (SIE) for the sector $62-92^{\circ} \mathrm{E}$ for the period AD 1708-2000. Annual $\mathrm{MS}^{-}$ concentration positively correlates in this sector with satellite-derived SIE for the period 1979-2000 $\left(r^{2}=0.25, P<0.02\right)$. The 293 year $\mathrm{MS}^{-}$record of proxy SIE shows multi-decadal variations, with large decreases occurring in two warm intervals during the Little Ice Age, and during the 1940s. It is very likely that the global temperature is the controlling factor of Antarctic sea-ice variation at the centennial scale, although there has been a change in phase between them in recent decades.
\end{abstract}

KEYWORDS: sea-ice growth and decay

\section{INTRODUCTION}

Sea-ice extent (SIE) is an important climate variable. It influences Earth's surface energy balance, and plays a major feedback role in climate changes at local to hemispheric scales. Large-scale measurements of Antarctic sea-ice extent are only available for the satellite era, since the 1970s. This hinders our understanding of the role of sea ice in climate forcing and of the mechanisms of long-term changes in SIE. For instance, in recent decades there has been a strong trend of declining Arctic sea-ice minimum extent, but a slightly increasing trend in Antarctic sea-ice maximum extent (Stroeve and others, 2012; Gagne and others, 2015). Whether these opposing responses to warming global average temperature are a long-term phenomenon, or have only appeared in recent decades, is unknown, largely because of the limited availability of reliable sea-ice records.

Although attempts have been made to reconstruct sea-ice extent in Antarctica from voyage and whaling records (e.g. Cotté and Guinet, 2007; De la Mare and William, 2009), the early data are sporadic, discontinuous and limited in time series. In the 1990s, methanesulfonate $\left(\mathrm{CH}_{3} \mathrm{SO}^{-}\right.$or $\left.\mathrm{MS}^{-}\right)$was found to be a sensitive proxy of SIE in some sectors of Antarctica (e.g. Welch and others, 1993). This is because $\mathrm{MS}^{-}$(an oxidation product of dimethylsulphide, DMS, which is produced by sea-ice algae) is released when sea ice decays, and there is hence a strong link between the extent of the ice and the amount of $\mathrm{MS}^{-}$produced.

Both positive (Welch and others, 1993; Myerson and others, 2002; Curran and others, 2003; Foster and others, 2006) and negative (Pasteur and others, 1995; Sun and others, 2002; Abram and others, 2007) correlations have been observed between MS $^{-}$and SIE for different sectors of Antarctica. Sneed and others (2011) found correlations with opposing sign for different sampling sites across the Antarctic interior, and Abram and others (2013) discussed site assessment and strategies for the further development of sea-ice histories from ice core $\mathrm{MS}^{-}$. But in the Indian Ocean sector, studies from Law Dome $\left(110^{\circ} \mathrm{E}\right.$; Curran and others, 2003) and Wilhelm II Land ( $86^{\circ} \mathrm{E}$; Foster and others, 2006) have shown positive correlation between $\mathrm{MS}^{-}$and SIE, suggesting that the relatively uniform coastline east of the Lambert Glacier basin (LGB) may be a good region to recover a long SIE record for the southern Indian Ocean (SIO). However, there are still large geographical gaps in such reconstruction, with one of the largest being in the western part of this sector. Here we analyze $\mathrm{MS}^{-}$records in an ice core extracted in January 2002 from site LGB69 $\left(70.83^{\circ} \mathrm{S}\right.$, $77.07^{\circ} \mathrm{E} ; 1850 \mathrm{~m}$ a.s.l.). This site is located on the coastal escarpment of the ice sheet, $\sim 160 \mathrm{~km}$ from the coast (Fig. 1).

\section{ICE-CORE AND SEA-ICE DATASETS AND THEIR RELATIONSHIP}

The LGB69 ice core was drilled in January 2002 in Princess Elizabeth Land, East Antarctica, during the 18th Chinese National Antarctic Research Expedition (CHINARE-18). The core was $102 \mathrm{~m}$ long and was dated by counting 293 annual cycles of multiple chemical species as well as known volcanic events (Li and others, 2012), with high dating accuracy ( \pm 1 year at the bottom). There is a high snow accumulation rate $\left(\sim 300 \mathrm{~kg} \mathrm{~m}^{-2} \mathrm{a}^{-1}\right)$ at LGB69, recorded both by an automatic weather station and with a stake array (Qin and others, 2004; Ding and others, 2011), and hence the ice-core records from this region allow resolution of annual climatic signals from the adjacent high latitudes of the SIO. Over this near-coastal area of Princess Elizabeth Land, the integrated tropospheric moisture flux is southwards (Xiao and others, 2004a). 


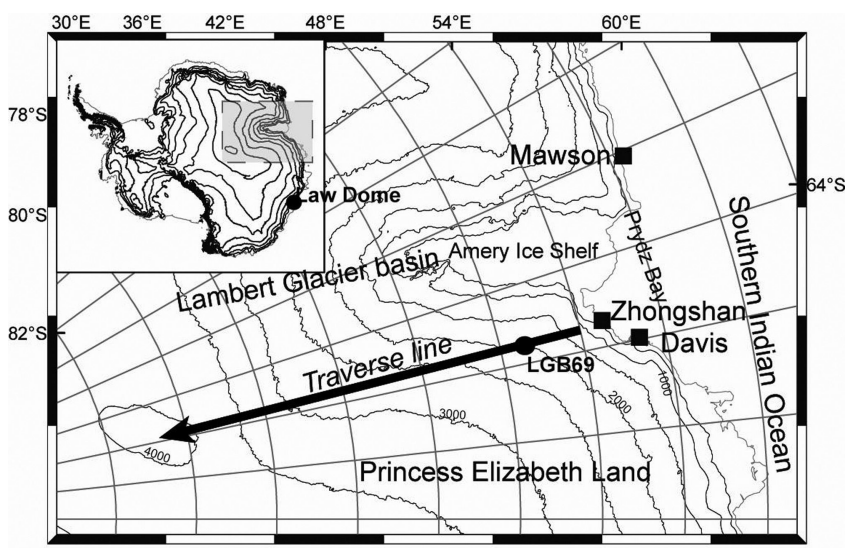

Fig. 1. Location of LGB69, Princess Elizabeth Land, East Antarctica.

The trace chemical records preserved in the Antarctic surface snow and ice showed that with increasing distance inland and elevation, there is a decreased dominance of marine air masses and an increase in stratospheric source (Bromwich, 1988; Mulvaney and Wolff, 1994; Legrand and Mayewski, 1997; Kreutz and Mayewski, 1999). Taking the 10 year sample 1991-99 as an example, we investigate the source of air masses reaching LGB69 by calculating backward trajectories, using the US National Oceanic and Atmospheric Administration (NOAA) HYSPLIT4 model (Draxler and Hess, 1997). European Centre for MediumRange Weather Forecasts ERA-40 re-analysis atmospheric circulation data were applied as atmospheric forcing field. We calculate the clustered mean backward trajectories for December (the time of strongest melting of sea ice and release of DMS) averaged for 1991-99. This indicates $46 \%$ of air parcels reaching LGB69 come from the $30-120^{\circ} \mathrm{E}$ sector of the SIO, while 54\% come from inland, probably via katabatic winds (Fig. 2). This is consistent with a result of an earlier study on LGB65 ice core $(140 \mathrm{~km}$ further south of LGB69) which showed that a quasi-stationary low-pressure system in the SIO provides precipitation to Princess Elizabeth Land (Xiao and others, 2004b).

Earlier studies suggested that $\mathrm{MS}^{-}$exhibits postdepositional movement, which may result in its loss from

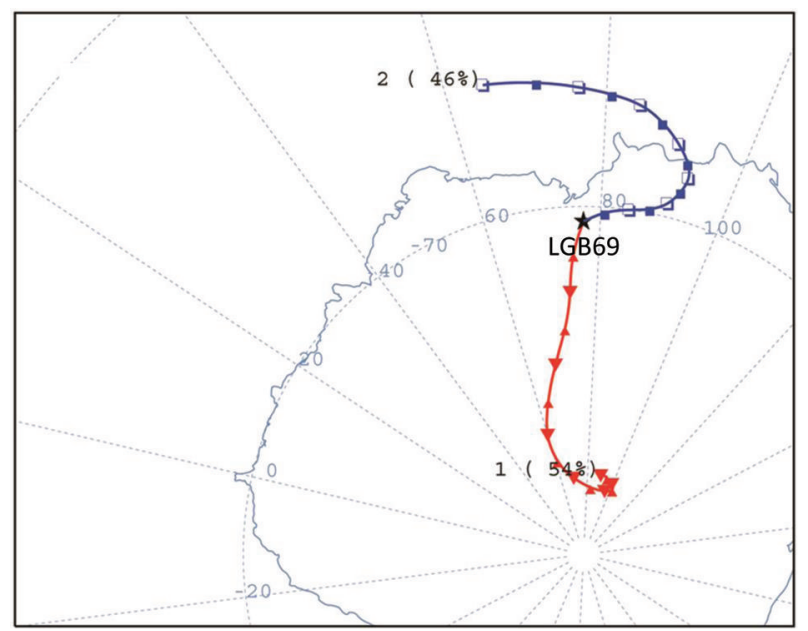

Fig. 2. Cluster means of backward air parcel trajectories arriving at LGB69 in December, 1991-99. The vertical level of the starting point is set at $1000 \mathrm{~m}$ a.g.I. (meters above ground level). A total of 1116 backward trajectories were integrated.
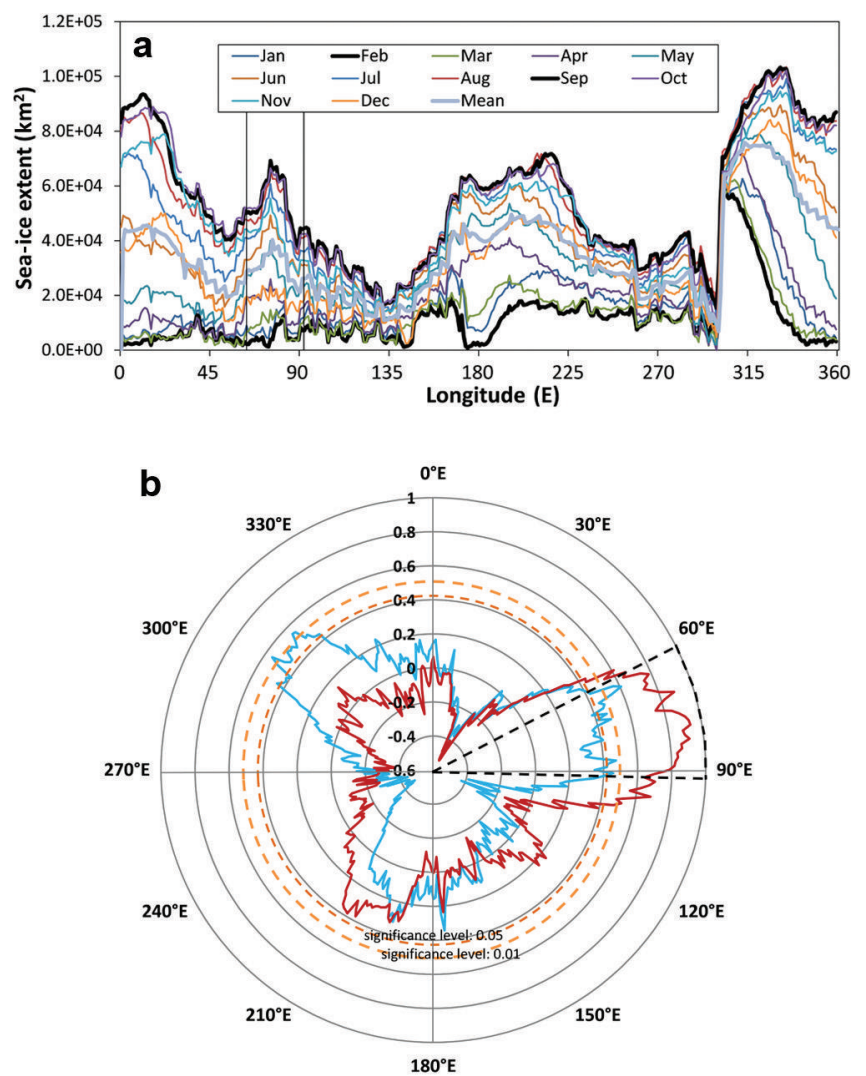

Fig. 3. (a) Average Antarctic SIE (area of ice within a $1^{\circ}$ longitude band) as a function of longitude in different months for 1979-2000. The vertical lines indicate the sector with the highest correlation between LGB69 $\mathrm{MS}^{-}$and seasonal maximum SIE. (b) Correlation of LGB69 $\mathrm{MS}^{-}$with the seasonal maximum SIE over the circumAntarctic (blue). The autocorrelation of SIE in the highest correlation sector with that at each longitude over the circum-Antarctic is also shown (red). Dashed circles are significance level of 0.05 and 0.01 respectively.

the snowpack (Pasteur and Mulvaney, 2000; Curran and others, 2002; Delmas and others, 2003). The movement of $\mathrm{MS}^{-}$is believed to be related to the accumulation rate and the concentration of other trace chemicals within the snowpack (Pasteur and Mulvaney, 2000). This is more common for ice cores in regions where low accumulation rates were observed. For $\mathrm{MS}^{-}$in the LGB69 record, there was no evidence of post-depositional movement (Mayewski and others, 2009). In the current study, annual records of $\mathrm{MS}^{-}$were compared to sea-ice extent records. The SIE dataset employed is based on US National Snow and Ice Data Center (NSIDC) sea-ice concentrations derived from passive microwave measurements from the Scanning Multichannel Microwave Radiometer (SMMR) on the Nimbus-7 satellite and from the Special Sensor Microwave/Imager $(\mathrm{SSM} / \mathrm{I})$ sensors on the US Defense Meteorological Satellite Program's (DMSP) F8, F11 and F13 satellites (Stroeve, 2003; Comiso, 2010). In this study, we use monthly sea-ice concentration data, with a spatial resolution of $25 \mathrm{~km} \times$ $25 \mathrm{~km}$, for January 1979 to December 2000, and the ice edge is defined at $15 \%$ concentration.

The mean monthly position of the SIE around Antarctica for 1979-2000 is shown in Figure 3a. The northernmost extent reaches $\sim 55^{\circ} \mathrm{S}$ over the sector $20-30^{\circ} \mathrm{E}$ at the seasonal maximum in September, and retreats as far south as 


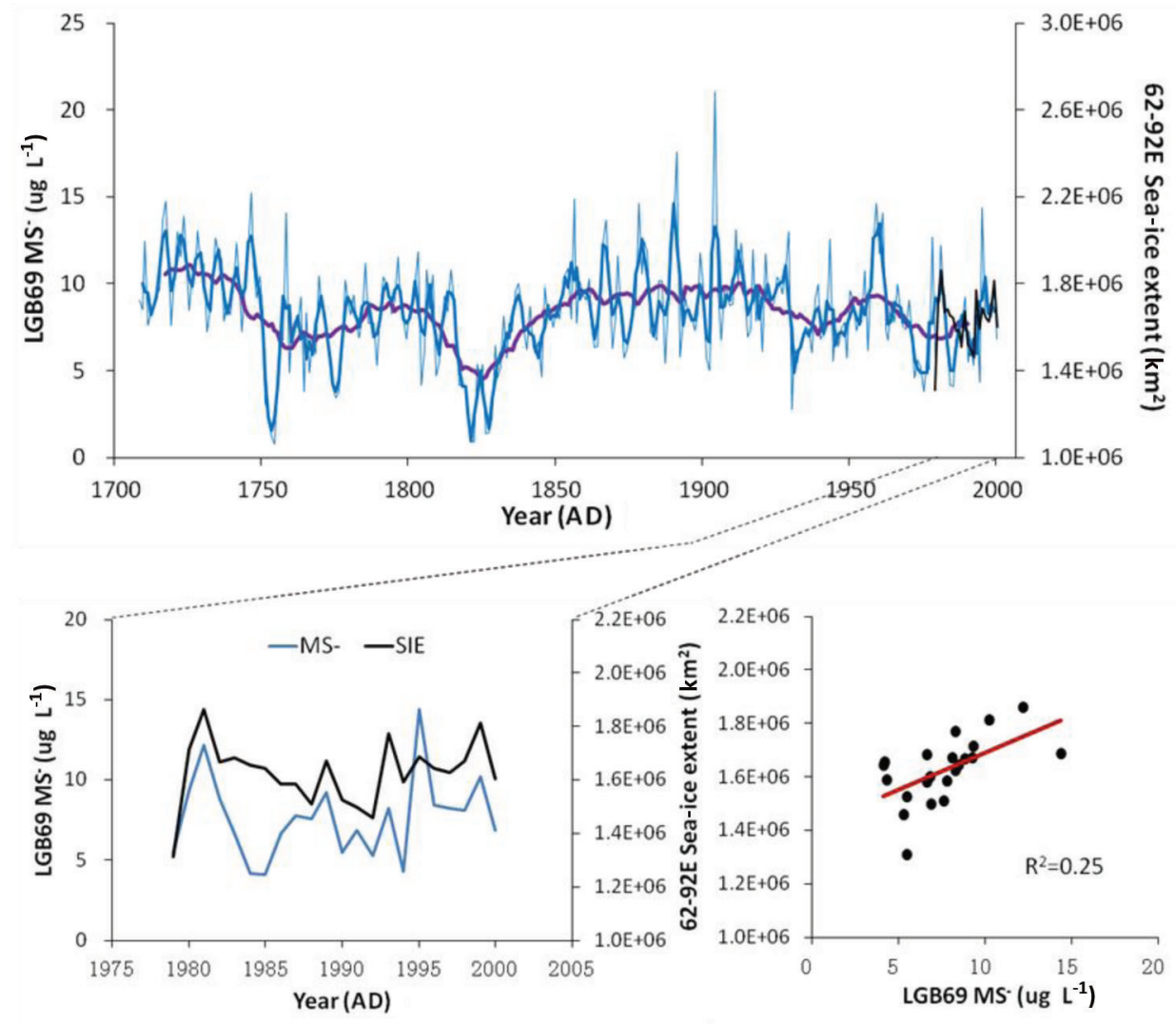

Fig. 4. Variations in LGB69 MS- since AD 1708 (blue, left axis) and in SIE since AD 1973 (black, right axis). The 3 year smoothed (thick blue) and 20 year smoothed (purple) MS- records are also shown. The series of MS $^{-}$and SIE for the last 22 years and their linear correlation are shown separately.

$\sim 75^{\circ} \mathrm{S}$ over the sector $180-190^{\circ} \mathrm{E}$ at the seasonal minimum in February. These extremes are due to ice drift resulting from complex oceanic and atmospheric circulation, particularly in the deep embayments of the Ross and Weddell Seas, which also produce the well-known sea-ice dipole between the two sectors (Yuan and others, 2001). Over the more uniform coastline of East Antarctica between $70^{\circ} \mathrm{E}$ and $150^{\circ} \mathrm{E}$, SIE changes have a relatively small seasonal amplitude, and are generally similar across the region. For the subsector $62-92^{\circ} \mathrm{E}$, the clockwise gyre circulation in Prydz Bay, north of the Amery Ice Shelf (Nunes Vaz and Lennon, 1996), results in a larger SIE than elsewhere in the SIO (Fig. 3a). In addition, from backward trajectory analysis, we can see this sector was the main source of $\mathrm{MS}^{-}$in the LGB69 ice core. Therefore, we focus on the relationship between $\mathrm{MS}^{-}$in LGB69 and sea ice over the SIO.

We correlate the annual average $\mathrm{MS}^{-}$(from June to the following July) in the LGB69 core with maximum SIE (average of August-October extent in the first winter of each record) over the circumpolar Antarctic for 1979-2000 (22 years inclusive). While this analysis is limited by the short satellite SIE record, it does show significant correlation. The highest correlation occurs over the sector $62-92^{\circ} \mathrm{E}$ $\left(r^{2}=0.25, P<0.02\right)$ (Fig. 3b). Although there are also correlations between LGB69 MS $^{-}$and SIE over other more distant sectors of the Southern Ocean, they are largely due to the autocorrelation of the maximum SIE there with SIE averaged for $62-92^{\circ} \mathrm{E}$ (red lines in Fig. 3b). Combined with the result of backward trajectory analysis, it can be concluded that $\mathrm{MS}^{-}$in LGB69 most strongly reflects the sea-ice changes over the $62-92^{\circ} \mathrm{E}$ sector of the SIO.
The 293 year $\mathrm{MS}^{-}$record from LGB69 in Figure 4 shows that there have been multi-decadal fluctuations of $\mathrm{MS}^{-}$(and thus of SIE in the $62-92^{\circ} \mathrm{E}$ sector) since $\mathrm{AD} 1708$. Large retreat of SIE occurred in the 1750s, 1830s, 1940s and 1980s. We compare this SIE proxy with the Northern Hemisphere temperature records from the Intergovernmental Panel on Climate Change (IPCC) Fourth Assessment Report (AR4), which are the HadCRUT2v temperature data since AD 1856; the CRUTEM2V data since AD 1781; and data from four European stations (central England, De Bilt, Berlin and Uppsala) since AD 1721 (Jansen and others, 2007). We found a general correspondence between the major cooling/warming cycles and SIE over approximately the last 300 years (Fig. 5) and with the variability at decadal and centennial scales

This consistency is not coincidental. Although circumpolar Antarctic SIE variations are not regionally coherent, SIE variations over the SIO are much more uniform than those of the Ross and Amundsen-Bellingshausen Seas (the Antarctic sea-ice dipole; Yuan and Martinson, 2001). The Indian Ocean sector $\left(62-92^{\circ} \mathrm{E}\right)$ explains $30 \%$ of the total variance of circumpolar SIE, suggesting that SIE variability in this sector, for which the LGB69 MS ${ }^{-}$provides a proxy, may reflect circumpolar SIE variability.

The $\mathrm{MS}^{-}$proxy SIE record (Fig. 5) shows SIE retreat during two relatively warm periods during the late Little Ice Age, in AD 1740-70 and 1820-40. Smaller SIE retreat can also be seen around a period of warming in the 1940s. In between these warm periods there is a relative expansion in SIE. We thus hypothesize that in the past the long-term circumpolar variation of Antarctic SIE was mainly controlled by the global 


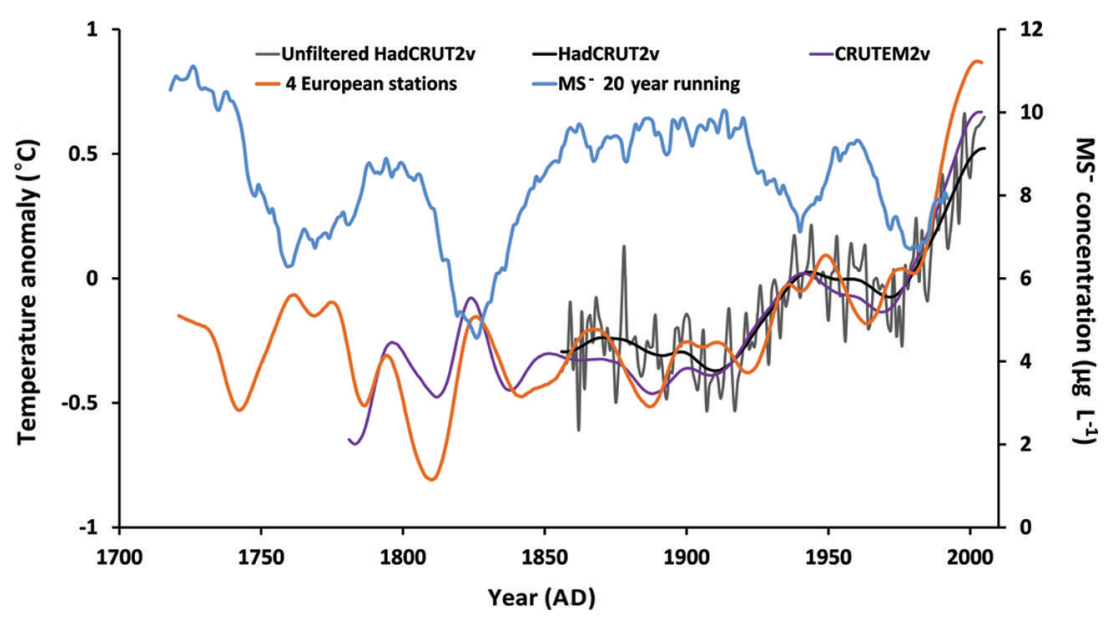

Fig. 5. Temperature changes in the Northern Hemisphere from IPCC AR4 (see legend) and the 20 year smoothed LGB69 MS ${ }^{-}$changes (blue).

temperature. However, more recently, warming in the late 1970s to early 1980s is associated with an expansion in SIE.

\section{SEA-ICE CHANGES OVER THE WIDER SOUTHERN INDIAN OCEAN}

In Figure 6, we compare the 20 year smoothed SIE anomalies from our proxy for $62-92^{\circ} \mathrm{E}$ with those derived by Curran and others (2003) for the sector $80-140^{\circ} \mathrm{E}$. The anomalies in both cases are calculated as the difference from the average proxy SIE for the 100 year period $1887-$ 1986 (inclusive). The average proxy SIE for the $62-92^{\circ} \mathrm{E}$ sector over this time is $58.7^{\circ} \mathrm{S}$, and for the $80-140^{\circ} \mathrm{E}$ sector, where the ice extent is narrower (Fig. 3a), it is $59.9^{\circ} \mathrm{S}$.

The two anomalies show general similarities in the timing of SIE changes, although there are differences in the magnitude of the change and in the finer detail. In particular, an increase in SIE from about the 1930s to the 1960s followed by a rapid decrease is indicated in both records, although the decrease for the $80-140^{\circ} \mathrm{E}$ sector is $\sim 1^{\circ}$ of latitude, whereas for $62-92^{\circ} \mathrm{E}$ it is $<1 / 2^{\circ}$ of latitude. Satellite observations show that trends in sea-ice extent are not uniform around Antarctica (e.g. Comiso and Nishio, 2008), and may even be of opposite sign in different regions. Sea-ice concentration trends may also be regionally out of phase (Comiso, 2010) and these differences have been linked to large-scale atmospheric circulation patterns and, in the case of the $62-92^{\circ} \mathrm{E}$ sector, to ocean circulation in the Prydz Bay Gyre. For example, Raphael (2007) shows a relationship between atmospheric zonal wave and

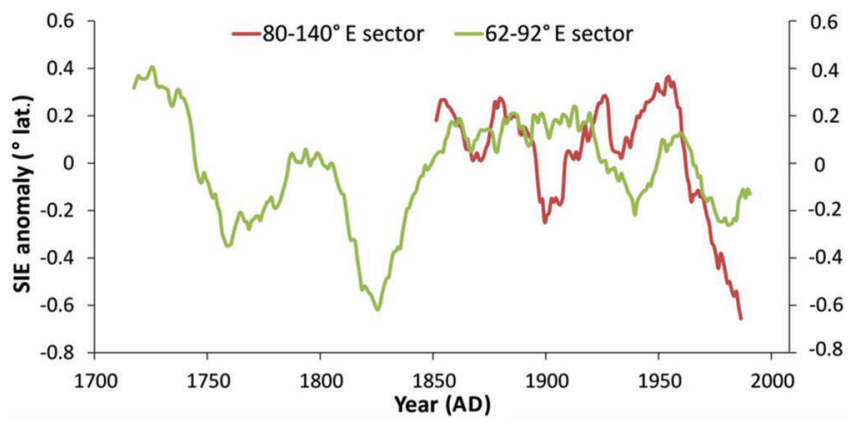

Fig. 6. Antarctic sea-ice extent anomalies for the $62-92^{\circ} \mathrm{E}$ sector (LGB69 proxy) and the $80-140^{\circ} \mathrm{E}$ sector (DSS proxy; from Curran and others, 2003). variability of Antarctic sea-ice concentration, with a strong positive correlation between the two occurring in our study area off the Amery Ice Shelf $\left(62-92^{\circ} \mathrm{E}\right)$. The proxy record for the $62-92^{\circ} \mathrm{E}$ sector shows a subsequent increase in SIE since $\sim 1985$, but this time segment is not covered in the record of Curran and others (2003).

\section{CONCLUSIONS}

Methanesulfonate from an ice core from LGB69 in Princess Elizabeth Land provides a proxy record of variations in Antarctic sea-ice extent between $62^{\circ} \mathrm{E}$ and $92^{\circ} \mathrm{E}$ over about the past 300 years. This provides a historical record additional to the result of Curran and others (2003). It is demonstrated from the LGB69 $\mathrm{MS}^{-}$records that SIE in the sector $62-92^{\circ} \mathrm{E}$ retreated during two relatively warm periods during the late Little Ice Age, in AD 1740-70 and 1820-40. Smaller SIE retreat can also be seen occurring in the 20th century, around the 1940s and in the late 1970s to early 1980s. The covariation between SIE of sector $62-92^{\circ} \mathrm{E}$ and global temperature supports the hypothesis that the Antarctic sea-ice variation at long-term scales is controlled by the global temperature change. However, further investigation is needed of the apparent change in phase between temperature and SIE in recent decades, and thus on whether the dominance of global temperature on the Antarctic seaice variation has decreased in the past decades.

This study has expanded the long-term variation of sea ice in the SIO. The proxy record of SIE for the $62-92^{\circ} \mathrm{E}$ sector shows similar broad trends to an earlier $\mathrm{MS}^{-}$proxy record (from a Law Dome ice core) for the adjoining $80-140^{\circ} \mathrm{E}$ sector. In particular there was a major decrease in SIE over the broader region from $~ 1950$ until the early 1980s. However, there are differences in the timing and magnitude of SIE trends in the two sectors. This highlights the fact that $\mathrm{MS}^{-}$records from ice cores generally provide proxy sea-ice information over only a limited longitude band, and that no single ice core record is likely to provide a good record of overall Antarctic sea-ice changes.

\section{ACKNOWLEDGEMENTS}

The study is supported by the Ministry of Science and Technology of China (MoST, 2013CBA01804), the National Nature Science Foundation of China (NSFC, 41425003, 
41421061, 41476164), the State Key Laboratory of Cryospheric Sciences (SKLCS-ZZ-2012-05), the Chinese Academy of Sciences and the Chinese Arctic and Antarctic Administration (CHINARE2013-01-02, 03). The contribution of I.A. was supported by a grant from the Chinese Academy of Sciences Visiting Professorship for Senior International Scientists (No. Y129N31001). We thank Mark Curran for providing proxy sea-ice data from the Law Dome DSS ice core. We also thank E. Thomas, I. Eisenman and two anonymous reviewers for valuable comments which helped substantially to improve this paper.

\section{REFERENCES}

Abram NJ, Mulvaney R, Wolff E and Mudelsee M (2007) Ice core records as sea ice proxies: an evaluation from the Weddell Sea region of Antarctica. J. Geophys. Res., 112(D15), D15101 (doi: 10.1029/2006JD008139)

Abram NJ, Wolff EW and Curran MAJ (2013) A review of sea ice proxy information from polar ice cores. Quat. Sci. Rev., 79, 168-183 http://eprints.esc.cam.ac.uk/id/eprint/2814

Bromwich DH (1988) Snowfall in high southern latitudes. Rev. Geophys., 26(1), 149-168 (doi: 10.1029/RG026i001p00149)

Comiso JC (2010) Polar oceans from space. Springer, Berlin (doi: 10.1007/978-0-387-68300-3)

Comiso JC and Nishio F (2008) Trends in the sea ice cover using enhanced and compatible AMSR-E, SSM/I, and SMMR data. J. Geophys. Res., 113(C2), C02S07 (doi: 10.1029/ 2007JC004257)

Cotté C and Guinet C (2007) Historical whaling records reveal major regional retreat of Antarctic sea ice. Deep-Sea Res., 54(2), 243-252 (doi: 10.1016/j.dsr.2006.11.001)

Curran MAJ and others (2002) Post-depositional movement of methanesulphonic acid at Law Dome, Antarctica, and the influence of accumulation rate. Ann. Glaciol., 35, 333-339 (doi: 10.3189/172756402781816528)

Curran MAJ, Van Ommen TD, Morgan VI, Phillips KL and Palmer AS (2003) Ice core evidence for Antarctic sea ice decline since the 1950s. Science, 302(5648), 1203-1206 (doi: 10.1126/ science.1087888)

De la Mare W and William K (2009) Changes in Antarctic sea-ice extent from direct historical observations and whaling records. Climate Change, 92, 461-493 (doi: 10.1007/s10584008-9473-2)

Delmas RJ, Wagnon P, Goto-Azuma K, Kamiyama K and Watanabe O (2003) Evidence for the loss of snow-deposited MSA to the interstitial gaseous phase in central Antarctic firn. Tellus B, 55(1), 71-79 (doi: 10.1034/j.1600-0889.2003.00032.x)

Ding $M$ and 6 others (2011) Spatial variability of surface mass balance along a traverse route from Zhongshan station to Dome A, Antarctica. J. Glaciol., 57(204), 658-666 (doi: 10.3189/ 002214311797409820)

Draxler RR and Hess GD (1997) Description of the Hysplit-4 modeling system. NOAA Tech. Memo. ERL ARL-224

Foster AFM, Curran MAJ, Smith BT, Van Ommen TD and Morgan VI (2006) Covariation of sea ice and methanesulphonic acid in Wilhelm II Land, East Antarctica. Ann. Glaciol., 44, 429-432 (doi: 10.3189/172756406781811394)

Gagne ME, Gillett NP and Fyfe JC (2015) Observed and simulated changes in Antarctic sea ice extent over the past 50 years. Geophys. Res. Lett., 42(1), 90-95 (doi: 10.1002/2014GL062231)

Jansen E and 15 others (2007) Palaeoclimate. In Solomon S and 7 others eds. Climate change 2007: the scientific basis. Contribution of Working Group I to the Fourth Assessment Report of the Intergovernmental Panel on Climate Change. Cambridge University Press, Cambridge and New York, ch. 6
Kreutz KJ and PA Mayewski (1999) Spatial variability of Antarctic surface snow glaciochemistry: implications for paleoatmospheric circulation reconstructions. Antarct. Sci., 11(1), 105-118 (doi: 10.1017/S0954102099000140)

Legrand M and Mayewski P (1997) Glaciochemistry of polar ice cores: a review. Rev. Geophys., 35(3), 219-243 (doi: 10.1029/ 96RG03527)

Li R, Xiao C, Sneed S and Yan M (2012) A continuous 293-year record of volcanic events in an ice core from Lambert Glacier Basin, East Antarctica. Antarct. Sci., 24, 293-298 (doi: 10.1017/ S0954102011000897)

Mayewski PA and 17 others (2009) The state of the Antarctic and Southern Ocean Climate System. Rev. Geophys., 47, RG1003 (doi: 10.1029/2007RG000231)

Mulvaney R and Wolff EW (1994) Spatial variability of the major chemistry of the Antarctic ice sheet. Ann. Glaciol., 20, 440-447 (doi: 10.3189/172756494794587159)

Myerson E, Mayewski PA, Kreutz KJ, Meeker LD, Whitlow SI and Twickler MS (2002) The polar expression of ENSO and sea-ice variability as recorded in a South Pole ice core. Ann. Glaciol., 35, 430-436 (doi: 10.3189/172756402781817149)

Nunes Vaz RA and Lennon GW (1996) Physical oceanography of the Prydz Bay region of Antarctic waters. Deep-Sea Res. I, 43(5), 603-641 (doi: 10.1016/0967-0637(96)00028-3)

Pasteur EC and Mulvaney R (2000) Migration of methane sulphonate in Antarctic firn and ice. J. Geophys. Res., 105(D9), 11 525-11 534 (doi: 10.1029/2000JD900006)

Pasteur EC, Mulvaney R, Peel DA, Saltzman ES and Whung PY (1995) A 340-year record of biogenic sulphur from the Weddell Sea area, Antarctica. Ann. Glaciol., 21, 169-174

Qin D and 6 others (2004) Snow surface height variations on the Antarctic ice sheet in Princess Elizabeth Land, Antarctica: 1 year of data from an automatic weather station. Ann. Glaciol., 39(1), 181-187 (doi: 10.3189/172756404781814546)

Raphael MN (2007) The influence of atmospheric zonal wave three on Antarctic sea ice variability. J. Geophys. Res., 112(D12), D12112 (doi: 10.1029/2006JD007852)

Sneed SB, Mayewski PA and Dixon DA (2011) An emerging technique: multi-ice-core multi-parameter correlations with Antarctic sea-ice extent. Ann. Glaciol., 52(57), 347-354 (doi: 10.3189/172756411795931822)

Stroeve J (2003) Sea Ice Trends and Climatologies from SMMR and SSM/I-SSMIS. NASA Distributed Active Archive Centre, National Snow and Ice Data Center, Boulder, CO. Digital media: nsidc.org/data/nsidc-0192

Stroeve J and 6 others (2012) Trends in Arctic sea ice extent from CMIP5, CMIP3 and observations. Geophys. Res. Lett., 39(16), L16502 (doi: 10.1029/2012GL052676)

Sun J, Ren J and Qin D (2002) 60 years record of biogenic sulfur from Lambert Glacier basin firn core, East Antarctica. Ann. Glaciol., 35, 362-367 (doi: 10.3189/172756402781817077)

Welch KA, Mayewski PA and Whitlow SI (1993) Methanesulphonic acid in coastal Antarctic snow related to sea ice extent. Geophys. Res. Lett., 20(6), 443-446 (doi: 10.1029/ 93GL00499)

Xiao C, Allison I, Ren J, Qin D, Zhang M and Li Z (2004a) Meteorological and glaciological evidence for different climatic variations on the east and west sides of the Lambert Glacier basin, Antarctica. Ann. Glaciol., 39(1), 188-194 (doi: 10.3189/ 172756404781814492)

Xiao C, Mayewski P, Qin D, Li Z, Zhang M and Yan Y (2004b) Sea level pressure variability over the southern Indian Ocean inferred from a glaciochemical record in Princess Elizabeth Land, east Antarctica. J. Geophys. Res., 109(D16), D16101 (doi: 10.1029/2003JD004065)

Yuan X and Martinson D (2001) The Antarctic Dipole and its predictability. Geophys. Res. Lett., 28(18), 3609-3612 (doi: 10.1029/2001GL012969) 